\title{
Long term treatment with luteinising hormone releasing hormone agonists and maintenance of serum testosterone to castration concentrations
}

\author{
FERNAND LABRIE， ANDRE DUPONT, ALAIN BELANGER， ROGER LACHANCE, \\ MICHEL GIGUERE
}

\begin{abstract}
Serum concentrations of luteinising hormone and testosterone were measured by radioimmunoassay one, two, four, seven, and 24 hours after the subcutaneous administration of $500 \mu \mathrm{g}$ of the luteinising hormone releasing hormone agonist [D-Trp ${ }^{6}$, des-Gly- $\left.\mathrm{NH}_{2}{ }^{10}\right]$ LHRH ethylamide or [D-Ser(TBU) ${ }^{6}$, des-Gly$\mathrm{NH}_{2}{ }^{10}$ LHRH ethylamide in patients who had previously received daily treatment with these peptides for $0,1,6,12,18$, and 24 months. No increase in the serum concentrations of luteinising hormone or testosterone were detected at any time between one and 24 months' treatment. The data show that daily subcutaneous administration of the two luteinising hormone releasing hormone agonists used at the appropriate dose can maintain concentrations of serum androgens equivalent to those after castration during long term treatment.
\end{abstract}

\section{Introduction}

Since the observation of Huggins et al in $1941^{1}$ the removal or blockage of testicular androgens by orchidectomy or oestrogens has been the principal form of treatment of advanced prostatic carcinoma. ${ }^{23}$ The psychological limitations of orchidectomy, however, are well recognised, and the high doses of oestrogens required for the complete inhibition of secretion of testicular androgens have serious cardiovascular side effects. ${ }^{45}$

During the past five years potent agonists of luteinising hormone releasing hormone have been shown to inhibit serum testicular androgens to castration concentrations without side effects other than those related to hypoandrogenism-namely, hot flashes and decrease or loss of libido..$^{6-13}$ It is important, however, that the inhibitory effect of these well tolerated peptides is maintained

Departments of Molecular Endocrinology and Medicine, Laval University Medical Center, Québec G1V 4G2, Canada

FERNAND LABRIE, MD, $\operatorname{FRCP}(\mathrm{C})$, professor of endocrinology

ANDRE DUPONT, MD, PHD, endocrinologist

ALAIN BELANGER, PHD, biochemist

ROGER LACHANCE, BSC, biochemist

MICHEL GIGUERE, MD, consultant during long term treatment. This is appropriate after the recent report of an increase of serum testosterone concentrations in three patients treated for six months with the luteinising hormone releasing hormone agonist ICI 118630 (Zoladex). ${ }^{14}$ About 450 patients at our clinic are treated with the luteinising hormone releasing hormone agonist [D-Trp ${ }^{6}$, des-Gly- $\left.\mathrm{NH}_{2}{ }^{10}\right] \mathrm{LHRH}$ ethylamide and the antiandrogen flutamide. We present detailed results in 12 randomly chosen patients who had taken serum luteinising hormone and testosterone for up to two years, having received no previous hormonal treatment.

\section{Patients and methods}

Twelve previously untreated patients with clinical stage DII prostate cancer with bone metastases visualised by scintiscans of bone were studied on day 1 of treatment and after one, six, 12, 18, and 24 months' combination treatment with a luteinising hormone releasing hormone agonist and the pure antiandrogen flutamide (Euflex). The agonist used was [D-Trp ${ }^{6}$, desGly- $\mathrm{NH}_{2}{ }^{10}$ ] LHRH ethylamide or [D-Ser(TBU) $)^{6}$, des-Gly- $\mathrm{NH}_{2}{ }^{10}$ ]LHRH ethylamide (buserelin). Binding of receptors as well as in vitro and in vivo assays in the rat and acute and long term effects of these two agonists in man indicated similar potency and efficacy. A daily subcutaneous dose of $500 \mu \mathrm{g}$ was given for one month followed by a $250 \mu \mathrm{g}$ dose except on the days that serial blood samples were taken, when a $500 \mu \mathrm{g}$ dose was given to provide a stronger stimulus and detect any escape of pituitary or testicular blockage, or both. Flutamide $250 \mathrm{mg}$ orally was given every eight hours starting 24 hours before the first injection of the agonist.

Serum samples were taken at the time of injection of $500 \mu \mathrm{g}$ luteinising hormone releasing agonist and one, two, four, seven, and 24 hours afterwards for measurements of serum luteinising hormone and testosterone concentrations by radioimmunoassay. ${ }^{13}$ Significance was assessed according to the multiple range test of Duncan-Kramer. ${ }^{15}$ All data are presented as means (SEM) of duplicate determinations for the 12 patients.

\section{Results and discussion}

The first administration of the luteinising hormone releasing hormone agonist caused about a fourfold increase in serum luteinising hormone concentrations measured one to 24 hours later $(\mathrm{p}<0.01$; fig $1(a))$. Serum testosterone concentrations, however, increased slowly during the first 24 hours to a value $50 \%$ above concentrations in controls at 24 hours $(p<0.05$; fig $2(a))$. Serum luteinising hormone concentrations, measured by radioimmuno- 
assay, decreased to $45 \%$ of the control value at one month and to roughly $30 \%$ of the control value between six and 24 months' treatment $(\mathrm{p}<0.01$; fig $1(b)-(f))$. Serum testosterone concentrations, however, decreased to $10 \%$ of those in controls at one month and remained at this low concentration thereafter $(\mathrm{p}<0.01$; fig $2(b)$ $(f)$ ). The most important finding was that there was no increase in either luteinising hormone or testosterone concentrations after the subcutaneous injection of $500 \mu \mathrm{g}$ of either luteinising hormone releasing hormone agonist used in our study.

Although in most studies the concentrations of serum testosterone measured 24 hours after administration of the luteinising hormone releasing hormone agonist are used as an index
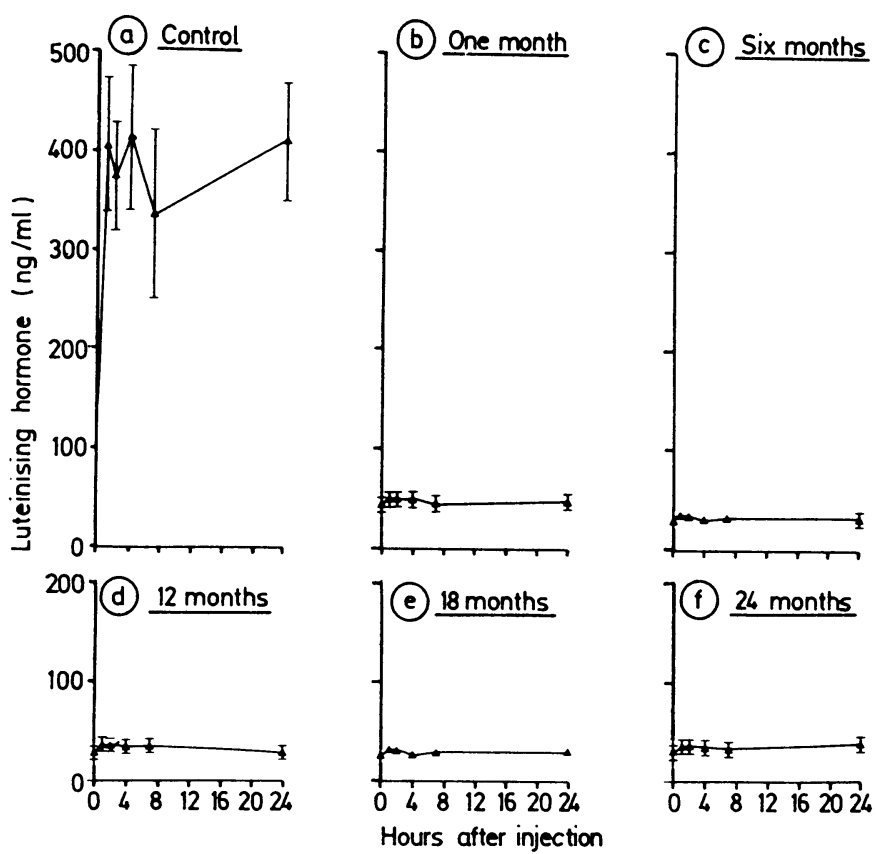

FIG 1-Response of radioimmunoassayed serum luteinising hormone concentration to administration of the agonist [D-Trp ${ }^{6}$, des-Gly- $\mathrm{NH}_{2}{ }^{10}$ ] LHRH ethylamide or [D$\operatorname{Ser}(\mathrm{TBU})^{6}$, des-Gly- $\mathrm{NH}_{2}{ }^{10}$ ]LHRH ethylamide on first day of treatment and after one, six, 12, 18, and 24 months' daily treatment. Basal concentrations of luteinising hormone were $94.9(12.7) \mathrm{ng} / \mathrm{ml}$. Bars represent SEM.
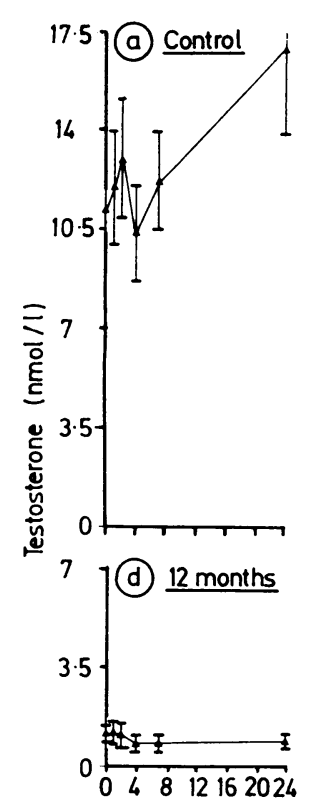
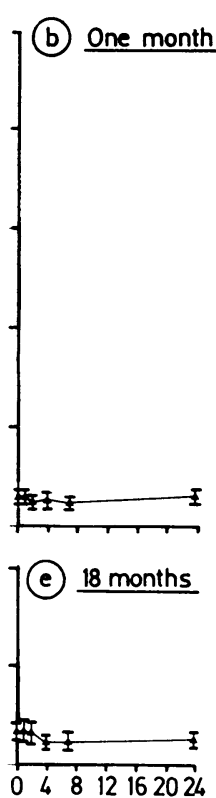

Hours after injection
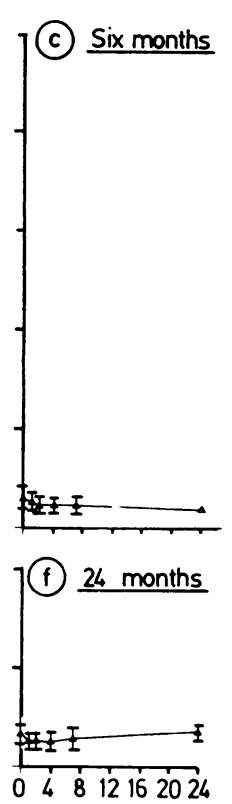

FIG 2-Response of radioimmunoassayed serum testosterone concentration to administration of agonist [D-Trp ${ }^{6}$, des-Gly- $\left.\mathrm{NH}_{2}{ }^{10}\right]$ LHRH ethylamide or [D-Ser(TBU) ${ }^{6}$, des-Gly- $\left.\mathrm{NH}_{2}{ }^{10}\right]$ LHRH ethylamide on first day of treatment and after one, six, 12, 18, and 24 months' daily treatment. Basal concentrations of testosterone were 11 $(1.7) \mathrm{nmol} / \mathrm{l}(3.18(0.49) \mathrm{ng} / \mathrm{ml})$. Bars represent SEM.

Conversion: SI to traditional units-Testosterone $1 \mathrm{nmol} / \mathrm{l} \approx 0.3 \mathrm{ng} / \mathrm{ml}$. of the efficacy of the peptides to inhibit testicular steroidogenesis, blood samples should be taken earlier to detect partial escape. ${ }^{16}$ When incomplete pituitary desensitisation is suspected, due to an inappropriate dose of the agonist, a lack of compliance, or use of a peptide with low activity, the increase in serum luteinising hormone and testosterone concentrations may be best seen two to seven hours after injection with a return to castration concentrations at 24 hours. ${ }^{16}$ Measurements of serum testosterone concentrations 24 hours after the subcutaneous administration of luteinising hormone releasing hormone agonists are thus a poor index of the efficacy of treatment with such agonists.

As there was no increase in serum luteinising hormone or testosterone concentrations measured two to three hours after injection in any of our 450 patients treated with a luteinising hormone releasing hormone agonist in combination with flutamide for up to three years, the increase in serum testosterone concentration seen in three of 10 patients treated for six months with ICI 118630 (Zoladex) by Kerle et al probably reflected a lack of compliance or a lower activity of the agonist used, or both. ${ }^{14}$ The availability of a depot formulation of the same peptide ${ }^{17}$ should eliminate the problem reported with its daily use. ${ }^{14}$

The use of the pure antiandrogen flutamide in association with a luteinising hormone releasing hormone agonist prevents any sign or symptom of disease flare seen in some cases when such agonists are used alone. ${ }^{18-20}$ As studied in detail in the dog, the antiandrogen does not interfere with the changes in secretion of gonadotrophin induced by the agonist (Lacoste, Bélanger, and Labrie, unpublished observations). The antiandrogen thus takes advantage of the otherwise extremely well tolerated luteinising hormone releasing hormone agonists to achieve medical castration. The only side effects observed were hot flashes in about half the patients and a decrease or loss of libido in about three quarters. ${ }^{16}$ The data show that long term treatment with daily subcutaneous injection of potent luteinising hormone releasing hormone agonists at the appropriate dose maintains serum testosterone concentrations to castration concentrations.

\section{References}

1 Huggins $\mathrm{C}$, Hodges $\mathrm{CV}$. Studies of prostatic cancer. I. Effect of castration, estrogen and androgen injections on serum phosphatases in metastatic carcinoma of the prostate. Cancer Res 1941;1:293-7.

2 Nesbit RM, Baum WC. Endocrine control of prostatic carcinoma: clinical and statistical survey of 1818 cases. FAMA 1950;143:1317-20.

3 Jordan WP Jr, Blackard CE, Byar DP. Reconsideration of orchiectomy in the treatment of advanced prostatic carcinoma. South Med f 1977;70:1411-3.

4 Hedlund PO, Gustafsson H, Sjogren S. Cardiovascular complications to treatment of prostatic cancer with estramustine phosphate (Estracyt) or conventional oestrogen. A follow-up of 212 randomised patients. Scand $\mathcal{Y}$ Urol Nephrol 1980;55(suppl): 103-5.

5 Glashan RW, Robinson MRG. Cardiovascular complications in the treatment of prostatic carcinoma. Br f Urol 1981;53:624-7.

6 Labrie F, Bélanger A, Cusan L, et al. Antifertility effects of LHRH agonists in the male. $f$ Androl 1980;1:209-28.

7 Labrie F, Dupont A, Bélanger A, et al. New hormonal therapy in prostatic carcinoma: combined treatment with an LHRH agonist and an antiandrogen. $f$ Clin Invest 1982;5:267-75.

8 Faure N, Labrie F, Lemay A, et al. Inhibition of serum androgen levels by chronic intranasal and subcutaneous administration of a potent luteinizing hormone-releasing hormone (LHRH) agonist in adult men. Fertil Steril 1982;37:416-24

9 Allen JM, O'Shea JP, Mashiter K, Williams G, Bloom SR. Advanced carcinoma of the prostate: treatment with a gonadotrophin releasing hormone agonist. Br Med f 1983;286:1607-9.

10 Walker KJ, Nicholson RI, Turkes AO, Turkes A, Griffits K. Therapeutic potential of the LHRH agonist, ICI 118630, in the treatment of advanced prostatic carcinoma. Lancet 1983;ii:413-5.

11 Waxman JH, Wass JAH, Hendry WF, et al. Treatment with gonadotrophin releasing hormone analogue in advanced prostatic cancer. Br Med f 1983;286:1309-12.

12 Wenderoth UK, Jacobi GH. Gonadotrophin-releasing hormone analogues for palliation of carcinoma of the prostate. World fournal of Urology 1983;1:40-8.

13 Labrie F, Dupont A, Bélanger A, et al. New approach in the treatment of prostate cancer: complete instead of only partial withdrawal of androgens. Prostate 1983;4:579-94.

14 Kerle D, Williams G, Ware H, Bloom SR. Failure of long-term luteinising hormone releasing hormone treatment for prostate cancer to suppress serum luteinising hormone and testosterone. BrMed f 1984;289:468-9.

15 Kramer CY. Extension of multiple-range tests to group means with unique numbers of replications. Biometrics 1956;12:307-10.

16 Labrie F, Dupont A, Bélanger A. Complete androgen blockade for the treatment of prostate cancer. In: De Vita VT Jr, Hellman S, Rosenberg SA, eds. Important advances in oncology. Philadelphia: J B Lippincott Co, 1985: 193-217.

17 Ahmed SR, Grant J, Shalet SM, et al. Preliminary report on use of depot formulation of LHRH analogue ICI 118630 (Zoladex) in patients with prostate cancer. Br Med $\mathcal{F}$ 1985;290:185-7.

18 Kahan A, Delrieu F, Amor B, Chiche R, Steg A. Disease flare induced by D-Trp ${ }^{6}$-LHRH analogue in patients with metastatic prostatic cancer. Lancet 1984;i:971-2.

19 The Leuprolide Study Group. Leuprolide versus diethylstilbestrol for metastatic prostate cancer. $N$ Engl f Med 1984;311:1281-6.

20 Labrie F, Dupon A, Bélanger A, Emond J, Monfette G. Simultaneous administration of pure antiandrogens, a combination necessary for the use of luteinising hormone-releasing hormone agonists in the treatment of prostate cancer. Proc Natl Acad Sci USA 1984;81:3861-3.

(Accepted 16 May 1985) 